\title{
Impact of e-CRM Implementation on Customer Loyalty, Customer Retention and Customer Profitability for Hoteliers along the Vaal Meander of South Africa
}

\author{
Job Dubihlela \\ Vaal University of Technology, \\ Vanderbijlpark, 1900, South Africa \\ Email:job@vut.ac.za \\ Palesa Molise - Khosa \\ Vaal University of Technology, \\ Vanderbijlpark, 1900, South Africa \\ Email: palesa.molise@gmail.com
}

\section{Doi:10.5901/mjss.2014.v5n16p175}

\begin{abstract}
The research approach is to appraise the impact of electronic customer relationship management (e-CRM) on customer profitability as mediated by customer loyalty and customer retention within the hotel industry sector of South Africa, and specifically for those hoteliers along the Vaal Meander. A sample of 341 middle to senior managers at various hotels was interviewed as respondents in this study. The objective of the study was to find the impact relationship between effective eCRM implementation, customer loyalty, customer retention and customer profitability. The findings of the study add value to hotels in South Africa, and provide some invaluable statistical results essential for hotel managers and owners to successfully enhance customer loyalty, customer retention and customer profitability. By applying both confirmatory factor analysis (CFA) and structural equation modelling (SEM), the results of our study identified and provide path analysis of the significant factors; and enumerated among the factors, those critical inter-component relationships within this highly competitive industry. This study's findings add to the body of knowledge and enable the managers of this sector to implement e-CRM in the best shape possible, to match it with South African market-needs thereby creating more loyal and repeat clientele. The future proposed further studies are also provided
\end{abstract}

Keywords: e-CRM, Customer loyalty, Customer retention, Hotel industry, Vaal Meander, South Africa

\section{Introduction}

One of the key developments in marketing has been the advent of electronic customer relationship management (e-CRM) systems, designed primarily to create and manage long lasting customer relationships. In today's age where firms are facing a radically different landscape, the process of relationship building between a company and its customers enhances lifetime value and increases profitability (Nguyen \& Mutum, 2012). Whist offering immediate advantages there are also many failure rates of e-CRM systems and e-CRM infrastructure (Vella \& Caruana, 2012). In this context, e-CRM is not only an instrument but a strategy for effective customer relationship management and a measurement for attitudes and intentions of customer retention and customer profitability in a competitive market.

Although some researchers have paid attention to e-CRM and e-CRM benefits (Ata \& Toker, 2012), little is known about a high failure rate of e-CRM implementation as the reasons for poor success rate are difficult to determine and contradictory research explanations are given (Finnegan \& Hamid, 2009). Furthermore, e-CRM has traditionally been associated with successful implementation. The continuing failure rate of e-CRM implementation conveys the need for further research. Some research findings report that CRM systems fail to have any impact and this also disappoints the business community at large (Xu \& Walton, 2005). For example, there is a premise that e-CRM automatically enables customised services without taking into consideration the different customer attitudes, preferences and intentions, cultures, ethics and languages thus failing to acquire and retain customers for the company's profitability. Consequently, organisations should limit the role of technology and situations in which it could be implemented successfully for customer relationship management (Moreno \& Padilla- Melendez, 2011).

Hotels are at the front end of the services industry sector and consequently are the "interface" from which 
consumers make their service requests. This suggests that the hotels industry sector is likely to be ahead of other industries in understanding e-CRM. We know that the majority of the top hotels have websites with at least some e-CRM features (Feinberg, Widdows, Wyncott, 1990). It is increasingly evident that e-CRM and advances in technology will continue to be a critical element in customer relationship management. Considering the issue of information systems (IS) and relationships, the literature is almost silent on customer satisfaction, during and after services (Kim, Park, Dubinsky \& Chai, 2012). Essentially, this research responds to a call for a new thinking where e-CRM failure rate, customer retention and profitability are not properly addressed. Some companies showed little interest to the survey that wanted to know how much improvement has been experienced due to e-CRM performance (Kimiloglu \& Zarali, 2009).

\section{Literature Review}

The advent of Internet technology has drastically changed how organisations foster relationships with their customers. Through the use of IT as an enabler many organisations have since redesigned their customer relationship management (CRM) to satisfy customer needs and create mutual and beneficial relationships (Moreno \& Padilla - Melendez, 2011). Electronic CRM entails the deployment of e-commerce functionalities to achieve the articulated goals of CRM. Customer relationship management (CRM) is a win-win strategy for understanding and treating customers better, for increased loyalty and profits. It is a comprehensive approach to manage the dynamic relationships with customers, which are evolutionary in nature (Finnegan \& Hamid, 2010). Thus, it provides the opportunity for continuous improvement on the customer service delivery. (Scullin, Fjermestad \& Romano, 2004).

However, for many organisations a success model for e-CRM cannot be successfully implemented to enhance customer experience, due to misalignment between customer requirements and existing systems. This in turn leads to high failure of e-CRM implementation. Despite the apparent benefits of e-CRM usage, thorough literature reviews highlights a worrying trend where attempt to implement CRM systems have failed (Vella \& Caruana, 2012). Therefore, failure in creating Information Systems (IS) processes that ascertain customer relationships and satisfaction during and after service cannot simply be overlooked. Failure to pay heed to the customer, the very major role player on whom CRM has to emanate (Kim, Park, Dubinsky \& Chaiy, 2012).

The integration between e-commerce and CRM lies in the organisation`s managing all aspects of relationships to increase customer loyalty and retention as well as an organistion`s profitability (Chong, Shafaghi \& Leing-Tan, 2011). ECRM implementation is central to effective customer relationship management. Today business processes are managed through information systems to improve relationships with customers (Finnegan \& Hamid, 2009). The CRM value chain spans across customer acquisition and customer retention. Organisations are implementing e-CRM throughout their various organisational units to improve a continuous adaptation and use of these systems. However, the importance and need of this should not be narrowly accepted as a success in itself (Akroush, Dahiyat, Gharaibeh \& Abu-Lail, 2011).

It is argued that the high failure rate of e-CRM implementation depends on organisational focus on customers. The major problem is not primarily infrastructure or hardware, but rather ineffective human level of interaction or system configuration that causes CRM failure (Vella \& Caruana, 2012). However, the lack of supportive and aligned information systems or infrastructure can also prevent the e-CRM from enhancing customer information quality (Kim et al., 2012). This challenge is caused by e-CRM processes that are too innovative and future-oriented by nature and are difficult to identify with for the organisation to remain sustainable (Kimiloglu \& Zarali, 2009).

CRM lies in cooperative and collaborative relationship between buyers and sellers to ensure all organisational decisions and actions are driven by the desire to achieve customer-centricity (Parker \& Castleman, 2009). The central focus on customers cannot be attained without retrospective analysis of customer attitudes and intention. The focus should not be on the technologies themselves but on how to facilitate customer management (Verhoef \& Lemon, 2013). This suggests that organisations should adapt e-CRM across business channels to enable timely and only relevant information to serve customers better (Finnegan \& Hamid, 2009). As a result, customers will view information systems as a way of improving their ability to use technology where their needs are met and solutions offered immediately. Furthermore, failing to understand customers attitudes and intentions and the degree of simplicity or difficulty when using e-CRM, may cause customers value to be destroyed. The less favourable a customer's attitude towards e-CRM implementation, the more skeptical will a customer be in how the company uses its information (Kim et al., 2013).

In view of limitations addressed in this literature the defective development and implementation of successful eCRM also lays in poorly planned customer retention tactics. Customer retention is centrally important aspect in e-CRM success (Kimiloglu \& Zarali, 2008), therefore research in e-CRM points out that other variables termed relationship marketing instruments (RMIs) or relationship marketing tactics (RMTs) like bonus and loyalty programmes, and retention rewards such as remembering customers` birthdays, would make customers feel appreciated and eager to continue 
relationships with the organisation (Nguyen \& Mutum, 2012; Hsieh, 2009). In other words when the above is undertaken, the frequency in which it is conducted increase customer retention, however care should be taken as not to imbalance frequency as this could lead to customer dissatisfaction as well as ineffective e-CRM implementation (Kim et al., 2012). Furthermore, customer retention must closely monitor the loyalty of customers, as a way of attaining high customer lifetime value.

According to (Xu \& Walton, 2005) lifetime value takes into account retention strategies used, and dual creation of value between the organisation and customers to enhance profitability (Nguyen \& Mutum, 2012). Profitability encompasses socio-economic factors and company capabilities, to adapt to the changing nature of business and technology environment and rules of competition (Finnegan \& Hamid, 2009). Thus, top management must implement the right technology with which to optimize the business processes and improve profitability. Verhoef and Lemon (2013) are of the view that technology, human and business resources be aligned with development of e-CRM infrastructure to compete with industry competition. The same authors point out that implementing e-CRM systems that may not be compatible with the company`s existing information systems and technology infrastructure may be detrimental (Parker \& Castleman, 2009). Therefore, caution should be taken with regards to other industries or nations that have different technologies and cultures. Today, the business landscape has changed and doing business globally cannot be seen as competing in a single market. Thus, companies must be more conscious on how they engage with globalised yet individualized and demanding customers.

\section{Theoretical Framework}

E-CRM is commonly considered as an information systems innovation because it has re-engineered the traditional marketing activities and has increasingly become important for business organisations to remain competitive in terms of nurturing long-term relationships with customers. However, there has been a relatively high failure rate for e-CRM implementation. System use is often recognized as one of the important indicators for its unsuccessful implementation and also demonstrates close correlation with other constructs such as customer loyalty, behavioural intentions, and customer retention and customer profitability which results in business performance. More specifically, an understanding of the determinants of actual behaviour toward using e-CRM should provide helpful insight for e-CRM systemsdevelopment and implementation, in particular, the stage of user requirements determination. As a result, taking from literature the relationships of the components under investigation are graphically illustrated in the following framework and hypothesized.

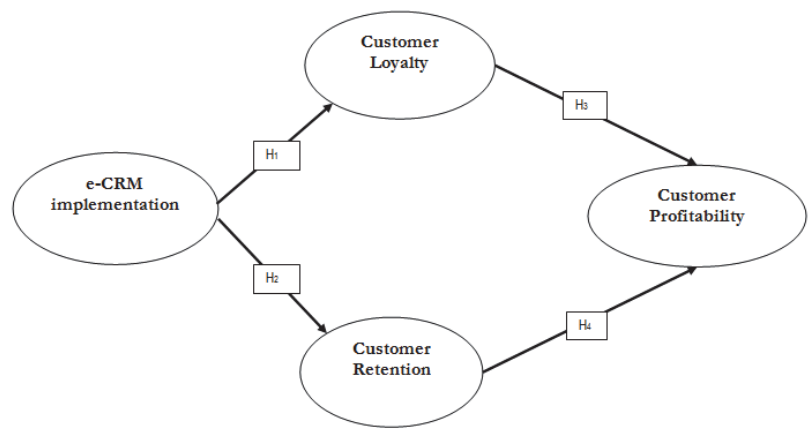

Figure 1: Conceptual Model

\subsection{Hypotheses}

In this conceptualized model e-CRM implementation is the predictor while customer profitability is the outcome as mediated by customer loyalty and customer retention. The conceptual model (Figure 1) depicts the research model with the hypothesized relationships and constructs linkages. In light of this view and also drawing from literature, e-CRM implementation is expected to impact positively on customer loyalty and customer retention capacity for hoteliers in South Africa. These mediating variables are expected to positively impact on customer profitability (Kapferer, 2008). The relationships have also been supported in prior empirical studies that focused their investigations on SMEs in general 
(Brodie, Winklhofer, Coviello \& Johnston, 2007). Accordingly, based on the illustrated relationships, the current study projects four hypotheses as follows:

H1: Implementation of e-CRM by hotels within the Vaal Meander has a positive impact on the loyalty of their customers

H2: Implementation of e-CRM by hotels within the Vaal Meander has a positive impact on their capacity to retain customers

H3: The loyalty of customers towards hotels has a direct positive impact on hoteliers' customer profitability

H4: Hoteliers' customer retention (capacity to retain customers) has a direct positive impact on customer profitability

\section{Research Methodology}

A quantitative approach was adopted in this study to establish the relationship between e-CRM implementation and the two mediating variables (customer loyalty and customer retention) as well as the outcome variable (customer profitability). The approach was deemed appropriate as it enabled the researchers to objectively test and confirm the hypotheses, and to explain the proposed benefits of e-CRM implementation among hotels in South Africa.

\subsection{Data collection}

The data collection process involved various types and classes of hotels operating along the Vaal Meander, bearing vast tourist attractions along the Vaal river of South Africa. Due to the nature of the research, the targeted research participants were the hotel managers and in other cases hotels' owner-managers. In particular, most interviewees were hotel officials who occupied middle to senior management positions. This was done to ensure the relevance of the data in evaluating the hotels' e-CRM implementation and its impact on the annotated components under investigation. Face to face, paper and pencil type interviews (PAPI) were done by the researchers with the help of trained fieldworkers.

\subsection{Instrument}

A structured questionnaire comprising a demographic section and four research constructs was used in line with the work of Connelly and Yoger (2001) as defining e-CRM and additional features from Feinberg et al. (2002), with necessary modifications made in order to fit the current research context and purpose. The questionnaire began with the demographic information section which also incorporated the business characteristics such as, number of years in business, number of employees, and the type and classification of hotel to which the hotel belongs. This data was needed to establish a detailed profile for the sample. The sections B to E covered the questions relating to the four annotated constructs (e-CRM implementation, customer loyalty, customer retention, and customer profitability). Entirely, the measurement variables were measured on a 5-point Likert-type scales that was anchored by $1=$ strongly disagree to $5=$ strongly agree to express the degree of agreement. A total of 341 usable questionnaires were retrieved for the final run of data analysis.

\section{Data Analysis}

\subsection{Respondents' age structure and levels of education}

Table 1 presents the age structure and the levels of education of the sample of respondents used in this study. Only 12.0 per cent $(n=41)$ of the respondents were under the age of 30 years, about a third $(30.2 \% ; n=103)$ of the respondents were aged between 30 and 39 years, 19.1 per cent $(n=65)$ reported their age to be between $50-59$ years, and a meagre 3.2 per cent $(n=11)$ of the respondents reported that they were 60 years and above. The majority of the respondents, 35.5 per cent $(n=121)$ were aged 40-49 years. From the illustrated data (Table 1), it can be said that the management's age structure within the hotels in South Africa are mainly within the age brackets of 30-59 years. This consequence is logical since managing and operating hotel-businesses is a challenging endeavour which requires experienced individuals who can make well-grounded decisions (Parker \& Castleman, 2009) and work long hours, especially strategic decisions. 
Table 1: Age of respondents and level of education

\begin{tabular}{|l|c|c|l|c|c|}
\hline Respondent's age & Frequency & $\%$ & Education level (respondent) & Frequency & $\%$ \\
\hline Below 30 yrs & 41 & 12.0 & No education (informal) & 0 & 0 \\
\hline From 30-39 yrs & 103 & 30.2 & Basic education (primary school) & 9 & 2.6 \\
\hline From 40-49 yrs & 121 & 35.5 & Matric education (grade 12) & 37 & 10.9 \\
\hline From 50-59 yrs & 65 & 19.1 & Trade certificate & 85 & 24.9 \\
\hline 60 yrs + & 11 & 3.2 & Undergraduate degree/diploma & 179 & 52.5 \\
\hline & & & Postgraduate degree/diploma & 31 & 9.1 \\
\hline Total & $\mathbf{3 4 1}$ & $\mathbf{1 0 0}$ & Total & 341 & 100 \\
\hline
\end{tabular}

With regards to respondents' levels of education, data (Table 1) reports that a staggering $86.5 \%(24.9 \%+52.5 \%+9.1 \%)$ of the respondents had at least a tertiary qualification (degree or diploma). This implies that the majority of the individuals who manage or run hotel businesses either had a hotel or trade certificate $(24.9 \%, n=85)$, an equivalent of a degree $(52.5 \%, n=179)$ or a postgraduate qualification $(9.1 \%, n=31)$. The remainder 13.5 per cent of the sample represents respondents who either possessed basic education or had matriculated $(2.6 \%+10.9 \%=13.5 \%)$.

\subsection{Other sample characteristics}

Table 2: Profile of sample characteristics

\begin{tabular}{|c|c|c|c|c|c|}
\hline Gender & Frequency & Percentage & Number of employees & Frequency & Percentage \\
\hline Male & 212 & $62.2 \%$ & $\leqq 20$ & 221 & $64.8 \%$ \\
\hline Female & 129 & $37.8 \%$ & $21-50$ & 81 & $23.8 \%$ \\
\hline & & & $\geqq 51$ & 39 & $11.4 \%$ \\
\hline Total & 341 & $100 \%$ & Total & 341 & $100 \%$ \\
\hline Marital status & Frequency & Percentage & Hotel Classification & Frequency & Percentage \\
\hline Married & 267 & $78.3 \%$ & & & \\
\hline Single & 74 & $21.7 \%$ & Less than 3-star & 117 & $34.3 \%$ \\
\hline & & & 3-star and above & 224 & $65.7 \%$ \\
\hline Total & 341 & $100 \%$ & Total & 341 & $100 \%$ \\
\hline
\end{tabular}

Table 2 reports that $64.8 \%$ ( $n=221$ ) of the respondents were from hotels that employed less than 20 workers each, while $23.8 \%(n=81)$ of the respondents indicated hotels that had a workforce between $21-50$ employees and a mere $11.4 \%$ $(n=39)$ reported between 51-100 employees. Regarding the gender of the participants, $62.2 \%(n=212)$ were male respondents while the remainder $37.8 \%$ ( $n=129)$ were female. In terms of hotel classification, the majority of the surveyed hotels were graded ' 3 -star and higher' as reported in the table $(65.7 \%, n=224)$. The study also reports most of the participants $(78.3 \%, \mathrm{n}=267)$ as being married.

\subsection{Reliability and validity of the measurements}

A reliability test, based on Cronbach's Alpha, was used to test the internal consistency of each construct (factor) and the results show all of them having acceptable internal consistency. Customer loyalty, customer retention, customer profitability and electronic customer relationship (e-CRM) have $\alpha$ values higher than 0.7 so their consistency is high (Cronbach, 1951; Nova` k, Christine, \& Abetz, 2004). Although some disparity emerged for customer retention which had 27 variables, extracted from models that other researchers proposed in previous researches. Clustering these variables resulted in 6 constructs (internal factors) being generated (Parker \& Castleman, 2009). These 6 sub-constructs were customer satisfaction, customer involvement, trust, attraction of alternatives, service quality, price, and switching barriers. Cronbach's Alpha was used to test the internal consistency of each construct (factor) and the results showed 4 sub-factors (Customer involvement, service quality, price, and switching barriers) having the $\alpha$ values higher than 0.7 , while customer satisfaction, trust, and attraction of alternatives were between 0.4 and 0.7 which showed normal consistency (Ware, Kosinski, \& Gandek, 1998) 
Table 3: Internal Consistency of factors with Cronbach's a

\begin{tabular}{|l|c|}
\hline Measurement constructs & Cronbach's $\boldsymbol{\alpha}$ \\
\hline eCRM implementation (eCRMi) & 0.892 \\
\hline Customer loyalty (CLoy) & 0.809 \\
\hline Customer retention (CRet) & 0.844 \\
\hline Customer Profitability (CPro) & 0.793 \\
\hline
\end{tabular}

The study performed a confirmatory factor analysis (CFA) to examine scale accuracy of the constructs using AMOS version 5. The CFA model includes the four research constructs which were assessed to check the model fit. The overall model statistics indicated acceptable model fit statistics (Ratio of chi-square (CMIN) to degrees of freedom (DF), the goodness-of-fit-index (GFI), the comparative-fit-index (CFI), the incremental fit index (IFI), the relative fit index (RFI), the normed fit index (NFI) and the root mean square error of approximation (RMSEA), where the ratio of CMIN to DF ( $\chi 2 / d f)$ is 2.491 and RMSEA is 0.239 . The indicators are considered statistically significant and therefore confirm the robustness and acceptable model fit of the construct measures (Bentler, 1990).

Composite reliability values were calculated and found to be above 0.8 , while the average variances extracted (AVE) indicated values above the 0.5 benchmark of Fornell and Larcker (1981). In addition, all the coefficient alpha values for the four constructs exceeded the threshold value of 0.7 , with all factor loadings significantly above the recommended thresh-hold of 0.6 (Malhotra, Kim, \& Patil, 2006). These indicators provided support for an acceptable degree of internal consistency, thereby satisfying convergent validity (Bryman \& Bell, 2011).

This study also investigated the constructs' distinctiveness by running discriminant validity tests in the order of Fornell and Larcker (1981). These were done through comparing the variance-extracted estimates of the measurements with the square of the parameter estimate between the measures. In line with Anderson and Gerbing (1988), the researchers further ascertained discriminant validity by performing chi-squire differences (constrained-unconstrained) in all two-factor CFA tests (which restricted the factor inter-correlations to unit). As such, all pairs of the constructs and the two-factor CFA tests results revealed adequate levels of discriminant validity. Overall, the two approaches used to check discriminant validity suggest that discriminant validity exist within the constructs under investigation.

\subsection{Model fit and hypotheses testing}

To test the validity of the proposed model and the hypotheses, a structural equation modelling (SEM) was run in AMOS version. The estimated model is presented in Table 4, illustrating the direction and magnitude of the impact of the standardized path coefficients (Malhotra et al., 2006).

Table 4: Results of structural equation model analysis

\begin{tabular}{|c|c|c|c|c|c|}
\hline Hypotheses & & Path & & $\begin{array}{c}\text { Estimate } \\
\text { coefficients }\end{array}$ & Result \\
\hline $\begin{array}{l}\text { H1: Implementation of e-CRM (e-CRMi) by hotels within the Vaal Meander has a } \\
\text { positive impact on the loyalty of their customers (CLoy) }\end{array}$ & CLoy & $<-$ & $\begin{array}{c}\mathrm{e}- \\
\mathrm{CRMi}\end{array}$ & $+0.619 b$ & Accepted \\
\hline $\begin{array}{l}\text { H2: Implementation of e-CRM (e-CRMi) by hotels has a direct positive impact on their } \\
\text { capacity to retain customers (CRet) }\end{array}$ & CRet & $<-$ & $\begin{array}{c}\mathrm{e}- \\
\mathrm{CRMi}\end{array}$ & $+0.243^{b}$ & Accepted \\
\hline $\begin{array}{l}\text { H3: The loyalty of customers (CLoy) towards hotels has a direct positive impact on } \\
\text { hoteliers' customer profitability (CPro) }\end{array}$ & CPro & $<-$ & CLoy & $+0.681^{b}$ & Accepted \\
\hline $\begin{array}{l}\text { H4: Hoteliers' customer retention (capacity to retain customers) (CRet) has a direct } \\
\text { positive impact on customer profitability (CPro) }\end{array}$ & CPro & $<-$ & CRet & $+0.237^{b}$ & Accepted \\
\hline
\end{tabular}

The overall structural equation model assessment showed acceptable model fit (Bagozzi, Yi \& Phillips, 1991); with the ratio of chi-square $(\mathrm{CMIN}=615.277)$ to degrees of freedom $(\mathrm{DF}=247)$, i.e. $(\chi 2 / \mathrm{df})=2.491$, the goodness-of-fit-index (GFI=0.893), the comparative-fit-index (CFI=0.887), the incremental fit index (IFI=0.897), the relative fit index $(\mathrm{RFI}=0.899)$, the normed fit index (NFI=0.889) and the root mean square error of approximation (RMSEA $=0.239$ ). As explained by these indicators, the model fit exhibits satisfactory parameters, thereby providing a good basis for testing the 
hypothesized paths (Xue, Ray \& Sambamurthy, 2013). The parameter estimates of the structural model showed that there are direct effects of one construct on the other, showing the existence of significant relationships among latent constructs (Chow \& Lui, 2001).

The results of path analysis as reported in Table 4 provide support for the entire proposed four research hypotheses. The path coefficients for $\mathrm{H} 1, \mathrm{H} 2, \mathrm{H} 3$, and $\mathrm{H} 4$ are $+0.619,+0.243,+0.681$ and +0.237 respectively. All hypothesis coefficients are significant at a confidence level ( $p$-value) of 0.01 .

\section{Discussion and Conclusion}

This study sought to examine e-CRM implementation (e-CRMi) and its impact on customer loyalty and customer retention within hotels in South Africa, and the resultant effect on their customer profitability. This was done in order to provide a theoretical grounding for the conceptualized framework which proposed that the outcome variable of e-CRMi is customer profitability (CPro). Specifically, the current study postulated four hypotheses and in order to test these hypotheses data were collected from hotel employees in South Africa. The empirical results supported all the postulated research hypotheses in a significant way.

Drawing from the findings of this research, both e-CRM implementation $(+0.619)$ and customer loyalty $(+0.681)$ showed stronger positive influence on hotels' customer profitability. Thus, in today's very competitive and constantly changing tourist business market, the South African hotel operators must consider customer loyalty, customer retention e-CRM implementation as very critical issues and constantly attempt to expand their e-CRM. Fjermestad and Romano (2003) posit that e-CRM can significantly help the information flow within the organization as well as improve its relationships with customers. All users have positive comments from the use of e-CRM in the tourist sector which should be considered as a channel for possible growth. Nevertheless, according to the findings, for the successful implementation of the system, vision and commitment from the management are needed. Strategic priority should be given to tangibility; scalability and flexibility that are important factors to construct the customer loyalty in South Africa. According to Adebanjo (2003), to effectively implement e-CRM, the priority should be given to personal compatibility, professional competence, frontline employees, quality of services and pricing policies. Accordingly, these findings can become useful marketing tools for the managers of the hotels and other related service organizations in developing economies (Laforet, 2013).

The findings thus, also confirm the importance of technology in the services industry sector and in contemporary business operations, with prevalent developments in electronic services integration growing in this sector. Yusuf, Guasekaran, Adeleye and Sivayoganathan (2004) refer to it as 'agility' (the ability of organisations to responds quickly to market changes), ability to be flexible in implementing recent technology as well as the ability to cope with competition. One surprise though in the current study is that customer retention revealed a relatively weak positive influence $(+0.237)$ on customer profitability. Perhaps, since there is a weak relationship between e-CRM implementation and customer retention, it might imply that prior measurements indirectly influenced the statistical indicator on customer profitability. Teece (2007) referred to this as 'the path dependencies', partly explaining the weak relationship between the two components.

\subsection{Implications of the study}

In South Africa, the tourism sector has been constantly growing and hoteliers are the biggest beneficiary of the growth. The current study therefore has some useful implications for both academicians and practitioners; practically contributing to the interactive literature and practice of hoteliers.

On the academic side, a contribution regarding the impact of e-CRM implementation within the services sector and particularly the hotel industry is made. Apart from the perceived benefits, the study also shows the challenges faced by hotels in implementing e-CRM to capture customer, retain customers and create customer loyalty. This will help other researchers to determine which aspect of e-CRM systems to focus on when developing interventions and growing business in the hotels industry sector. The findings are also useful for business owners within the hotels industry as they confirmed the prominence of e-CRM implementation as a precursor to improved customer retention, increased customer loyalty. However, the implementation of new technologies might require the hoteliers to also adjust their organizational structure and improve employees and management skills in order to achieve high levels of efficiency. It is imperative that hoteliers accordingly adjust for instance, their organizational structure, human capital needs, operational strategies and technologies in tandem with the challenges that come with the processes and implementation of e-CRM. Given that improved customer profitability might imply high revenue and business performance, indeed managers and hotel owners 
that have not effectively utilized e-CRM systems yet, can increase their organizational profitability by integrating e-CRM and investing to enhance e-CRM capabilities.

In a nutshell, this study submits that the hoteliers and their managers can successfully improve their customer profitability and business performance by exploiting their relationship management strategies through restructuring operations and implementing e-CRM. Eventually, a successful e-CRM system is expected to boost customer loyalty, retain profitable customers and generate more revenue for the hotels, hence their overall performance and survival.

\subsection{Limitations and proposed future research}

While the study makes significant contributions to the body of knowledge, it endures some limitations that provide avenues for further research directions. The study used cross-sectional data from a relatively small sample. It is expected that the results might differ if a larger sample covering the other regions of South Africa. A richer understanding of the relationships between this study's research constructs might be expected if longitudinal data were used. The study investigated only the hotels industry sector, the results could differ if research would be carried out on the whole services sector, to provide a clearer picture of the extent of e-CRM implementation, challenges and benefits country-wide. The fact that the survey participants were mangers can have influence on the method bias in the results. Therefore, future survey researches should attempt to incorporate secondary source data in order to provide further insight into the impact of eCRM implementation; also collecting data from customers could yield different results

\section{References}

Adebanjo, D. (2003). Classifying and Selecting e-CRM Applications: An Analysis-Based Proposal. Management Decision, 41(6), $570-$ 577.

Akroush, M.N., Dahiyat, S.E., Gharaibeh, H.S. \& Abu-Lail, B.N. (2011). Customer relationship management implementation: An investigation of a scale's generalizability and its relationship with business performance in a developing country context. International Journal of Commerce and Management, 21(2), 158-190.

Anderson, J.C. \& Gerbing D.W. (1988). Structural equation modeling in practice: a review and recommended two step procedure. Psychological Bulletin, 103 (3), pp 411-423.

Ata, U.Z. \& Toker, A. (2012). The effect of customer relationship management adoption in business-to-business markets. Journal of Business \& Industrial Marketing, 27(6), pp.497 - 507.

Bagozzi, R. P., Yi Y.\& Phillips, L. W. (1991). Assessing construct validity in organizational Research. Administrative Science Quarterly, 36(3), pp 421-458.

Bentler, P.M. (1990). Comparative Fit Indexes in Structural Equation Modeling. Psychological Bulletin, 107 (2), pp 238-46.

Brodie, R. J., Winklhofer H., Coviello N. E. \& Johnston, W. J. (2007). Is e-retailing coming of age? An examination of the penetration of e-retailing and firm performance. Journal of Interactive Marketing, 21(1), pp 2-21.

Bryman, A. \& Bell, E. (2011). Business research methods, 3rd edition, New York: Oxford University Press Inc.

Chong, W.K., Shafaghi, M. \& Tan, B.L. (2011). Development of a business-to-business critical success factors (B2B CSFs) framework for Chinese SMEs. Marketing Intelligence \& Planning, 29(5), pp.517-533.

Chow, W.S., \& Lui, K.H. (2001). Discriminating factors of information systems function performance in Hong Kong firms practicing TQM. International Journal of Operation \& Production Management, 21(5/6), 749-771.

Connelly, P.J. \& Yoger, T. (2001). Can CRM win and retain loyal repeat customers? Information World, (1) pp.58-9.

Cronbach, L. (1951). Coefficient alpha and the internal structure of tests. Psychometrika, 16, 297334.http://dx.doi.org/10.1007/BF02310555. Accessed 13 March 2014

Feinberg, R., Widdows, R., Wyncott, M. \& Trappey, C. (1990). Myth and reality in customer service: good and bad service sometimes leads to repurchase. Journal of Customer Satisfaction, Dissatisfaction and Complaining Behavior, 12(3), pp.112-15.

Finnegan, D. \& Hamid, K. (2009). Information systems (IS) integration approaches in healthcare: a critical review. Information systems. In: Currie W, Finnegan D, editors.Integrating healthcare with information and communications technology. United Kingdom: Radcliffe Publishing Ltd. p35-63.

Fjermestad, J. \& Romano, N. C. (2003). Electronic customer relationship management: revisiting the general principles of usability and resistance: an integrative implementation framework. Business Process Management Journal, 9(5), 572-591.

Fornell C.R. \& Larcker, D.F. (1981). Evaluating structural equation models with unobservable variables and measurement error. Journal of Marketing Research, 18 (1), pp 39-50.

Garrido-Moreno, A., \& Padilla-Meléndez, A. (2011). Analyzing the impact of knowledge management on CRM success: The mediating effects of organizational factors. International Journal of Information Management, 31(5), pp.437-444.

Kapferer J.N. (2008). The new strategic brand management: creating and sustaining brand equity long term. $4^{\text {th }}$ edition, Kogan Page, London, UK.

Kim, M., Park, J.E., Dubinsky, A.J. \& Chaiy, S. (2012). Frequency of CRM implementation activities: A customer-centric view. Journal of Services Marketing, 26(2), pp.83-93. 
Kimiloglu, H. \& Zarali, H. (2009). What signifies success in e-CRM? Marketing Intelligence \& Planning, 27(2), pp.246-267.

Laforet, S. (2013). Organisational innovation outcomes in SMEs: Effects of age, size and sector. Journal of World Business, 48 (3), pp.490-502.

Malhotra, N. K., Kim, S. S., \& Patil, A. (2006). Common method variance in IS research: A comparison of alternative approaches and a reanalysis of past research. Management Science, 52(12): 1865-1883.

Nguyen, B. \& Mutum, D.S. (2012). A review of customer relationship management : successes, advances, pitfalls and futures. Business Process Management Journal, 18(3), pp.400-419.

Nova'k, A., Christine, L., \& Abetz, L. (2004). Development and validation of an acceptability and satisfaction questionnaire for a contraceptive vaginal ring. Pharmaco Economics, 22(4), pp.245-256.

Parker C.M. \& Castleman T. (2009). Small firm e-Business adoption: A critical analysis of Theory. Journal of Enterprise Information Management, 22 (1/2), pp. 167-182.

Scullin, S.S., Fjermestad, J. \& Romano, N.C. (2004). E-relationship marketing: changes in traditional marketing as an outcome of electronic customer relationship management. Journal of Enterprise Information Management, 17(6), pp.410-415.

Shu-Hui, C. \& Hong-Nan, L. (2013). The roles of infrastructure capability and customer orientation in enhancing customer-information quality in CRM systems: Empirical evidence from Taiwan. International Journal of Information Management, 33, pp.271 281.

Teece D. J. (2007). Dynamic capabilities and multinational enterprise: Penrosean insights and Omissions. Management International Review, 47 (2), pp 175-192.

Vella, J. \& Caruana, A. (2012). Encouraging CRM systems usage: A study among bank managers. Management Research Review, 35(2), pp.121-133.

Verhoef, P.C. \& Lemon, K.N. (2013). Successful customer value management: Key lessons and emerging trends. European Management Journal, 31(2), pp.1-15.

Ware, J., Kosinski, M., \& Gandek, D. (1998). The factor structure of the health survey in 10 countries. International Quality of Life Assessment, 51(3), pp.159-165.

Xu, M. \& Walton, J. (2005). Gaining customer knowledge through analytical CRM. Industrial Management \& Data Systems, 105(7), pp.955-971.

Xue, L., Ray, G., \& Sambamurthy, V. (2013). The impact of supply chain electronic integration on customer service performance. Journal of Operations management, 82(9), 1-13.

Yusuf, Y.Y., Guasekaran, A., Adeleye, E.O., \& Sivayoganathan, K. (2004). Agile supply chain capabilities: Determinants of competitive objectives. European Journal of Operational Research, 159, pp.379-392. 